University of Wollongong

Research Online

Faculty of Engineering and Information

Faculty of Engineering and Information

Sciences - Papers: Part A

Sciences

$1-1-2013$

Net section tension capacity of cold-reduced sheet steel angle braces

bolted at one leg

Lip H. Teh

University of Wollongong, Iteh@uow.edu.au

Benoit P. Gilbert

Griffith University, b.gilbert@griffith.edu.au

Follow this and additional works at: https://ro.uow.edu.au/eispapers

Part of the Engineering Commons, and the Science and Technology Studies Commons

Research Online is the open access institutional repository for the University of Wollongong. For further information contact the UOW Library: research-pubs@uow.edu.au 


\title{
Net section tension capacity of cold-reduced sheet steel angle braces bolted at one leg
}

\begin{abstract}
This paper examines the accuracy of equations specified by the North American and Australasian steel structures codes for determining the net section tension capacity of a cold-formed steel angle brace bolted at one leg. The configurations tested in the laboratory include single equal angle, single unequal angle bolted at the wider leg, single unequal angle bolted at the narrow leg, double angles, and alternate angles. The steel materials used in the experiment are among those with the lowest ductility for which nominal tensile strength is permitted by cold-formed steel design codes to be fully utilized in structural design calculations. Based on a modification to the equation derived for channel braces bolted at the web, a design equation is proposed for determining the net section tension capacity of a cold-formed steel angle brace bolted at one leg. The proposed equation is demonstrated, through laboratory tests on 61 specimens composed of G450 sheet steel, to be more accurate than the code equations and those existing in the literature. DOI: 10.1061/(ASCE)ST.1943-541X.0000675. (C) 2013 American Society of Civil Engineers.
\end{abstract}

\section{Keywords}

angle, steel, sheet, reduced, leg, cold, one, capacity, tension, section, net, bolted, braces

\section{Disciplines}

Engineering | Science and Technology Studies

\section{Publication Details}

Teh, L. H. \& Gilbert, B. P. (2013). Net section tension capacity of cold-reduced sheet steel angle braces bolted at one leg. Journal of Structural Engineering, 139 (3), 328-337. 


\title{
Net Section Tension Capacity of Cold-Reduced Sheet Steel Angle Braces Bolted at One Leg
}

\author{
Lip H. Teh, A.M.ASCE ${ }^{1}$; and Benoit P. Gilbert ${ }^{2}$
}

\begin{abstract}
This paper examines the accuracy of equations specified by the North American and Australasian steel structures codes for determining the net section tension capacity of a cold-formed steel angle brace bolted at one leg. The configurations tested in the laboratory include single equal angle, single unequal angle bolted at the wider leg, single unequal angle bolted at the narrow leg, double angles, and alternate angles. The steel materials used in the experiment are among those with the lowest ductility for which nominal tensile strength is permitted by cold-formed steel design codes to be fully utilized in structural design calculations. Based on a modification to the equation derived for channel braces bolted at the web, a design equation is proposed for determining the net section tension capacity of a cold-formed steel angle brace bolted at one leg. The proposed equation is demonstrated, through laboratory tests on 61 specimens composed of G450 sheet steel, to be more accurate than the code equations and those existing in the literature. DOI: 10.1061/(ASCE)ST.1943-541X.0000675. @ 2013 American Society of Civil Engineers.
\end{abstract}

CE Database subject headings: Bolted connections; Cold-formed steel; Shear lag; Tensile strength; Thin wall sections; Bracing.

Author keywords: Bolted connections; Cold-formed steel; Shear lag; Tensile strength; Thin wall sections.

\section{Introduction}

The net section tension capacity of a bolted connection in a coldformed steel angle brace is specified in Supplement No. 2 to the North American Specification for the Design of Cold-formed Steel Structural Members 2007 [American Iron and Steel Institute (AISI) 2010] and in the Australasian code AS/NZS 4600:2005 [Standards Australia/Standards New Zealand (SA/SNZ) 2005]. For an angle brace that is bolted at one leg only, the tension capacity equations in the two codes have different forms from each other.

The design equation specified in the North American coldformed steel structures code (AISI 2010) results from a modification to the equation proposed by Chesson (1959) to account for shear lag in a tension member in which not all of its cross-sectional elements are bolted to the joining member. The shear lag causes the tension stresses to be nonuniformly distributed across the critical net section, resulting in a lower tension capacity than otherwise would be the case. The shear lag factor, termed the net section efficiency factor in the present work for reasons explained by Teh and Gilbert (2013) in the North American cold-formed steel structures code, is a function of the connection eccentricity and the connection length only.

Maiola et al. (2002) and de Paula et al. (2008) found the design equation specified in the North American cold-formed steel structures code to be unconservative based on their laboratory test results. The steel materials used by Maiola et al. (2002) had ratios of tensile strength to yield stress not less than 1.35 , and that used by de Paula et al. (2008) had a nominal ratio of 1.40 .

\footnotetext{
${ }^{1}$ Senior Lecturer, School of Civil, Mining and Environmental Engineering, Univ. of Wollongong, Wollongong, NSW 2500, Australia (corresponding author). E-mail: 1teh@uow.edu.au

${ }^{2}$ Lecturer, School of Engineering, Griffith Univ., Gold Coast, QLD 4222, Australia.

Note. This manuscript was submitted on December 19, 2011; approved on June 5, 2012; published online on August 11, 2012. Discussion period open until August 1, 2013; separate discussions must be submitted for individual papers. This paper is part of the Journal of Structural Engineering, Vol. 139, No. 3, March 1, 2013. (CASCE, ISSN 0733-9445/2013/3-328-337/\$25.00.
}

The design equation specified in the Australasian code (SA/SNZ 2005) makes use of neither the section's geometric properties nor the connection length. For single equal angle braces or single unequal angle braces bolted at the wider leg, the net section efficiency factor is constant at 0.85 . For single angle braces bolted at the narrow leg, it is 0.75 . The Australasian code specifies the net section efficiency factor for double angle braces connected back-to-back to be unity.

Kulak and $\mathrm{Wu}$ (1997) tested hot-rolled steel angle sections with a nominal ratio of tensile strength to yield stress equal to 1.50 , and found that there was no significant difference in the net section efficiency between single angle braces and double angle braces. They proposed a net section efficiency factor that is a function of the ratio of the yield stress to the ultimate tensile strength of the steel material and the number of bolts in the connection.

Teh and Gilbert (2013) have shown that existing equations for determining the net section tension capacity of bolted connections in channel braces are too optimistic for those composed of coldreduced, high-strength sheet steels caused by the latter's lower ductility, which limits their ability to redistribute stresses away from the stress concentration areas. In this regard, the cold-formed steel angle braces tested in the literature (Holcomb et al. 1995; Maiola et al. 2002; de Paula et al. 2008) were composed of materials that were significantly more ductile than the newer generation of coldreduced, high-strength sheet steels (Hancock 2007).

The present work aims to formulate a simple design equation that is reliable in predicting the net section tension capacity of bolted connections in low ductility cold-formed steel angle braces. For this purpose, laboratory tests on angle braces bolted at only one leg were conducted. The configurations tested in the laboratory are single equal angle, single angle bolted at the wider leg, single angle bolted at the narrow leg, double angles, and alternate angles as depicted in Fig. 1. The sections were made of G450 sheet steels by brake pressing.

Teh and Gilbert (2013) proposed an equation for determining the net section tension capacity of a channel brace bolted at the web, which was demonstrated through laboratory tests of channels composed of G450 sheet steels to be quite accurate. They also found 


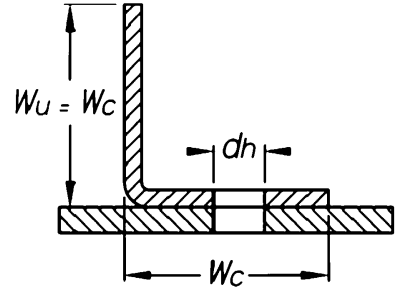

(a) Single equal angle

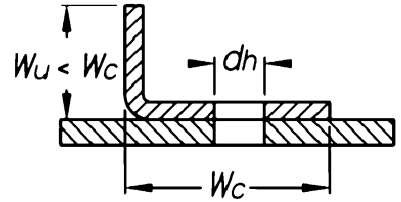

(b) Single angle bolted at the wider leg

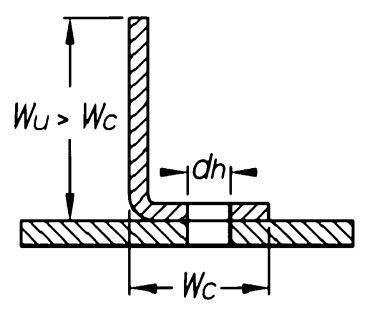

(c) Single angle bolted at the narrow leg

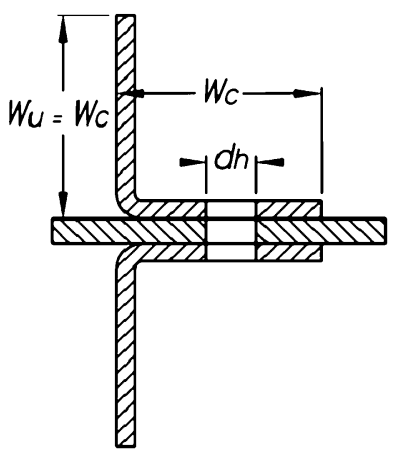

(d) Double equal angle

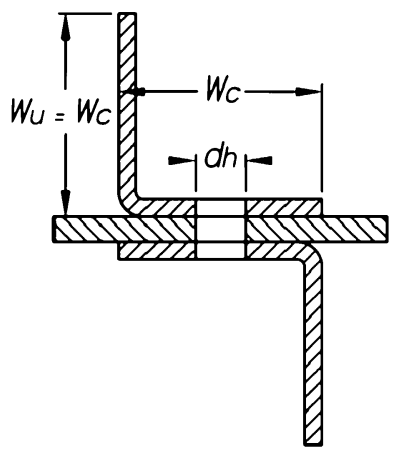

(e) Alternate equal angle

Fig. 1. Configurations of tested specimens: (a) single equal angle; (b) single angle bolted at the wider leg; (c) single angle bolted at the wider leg; (d) double equal angle; (e) alternate equal angle

the equation derived by Holcomb et al. (1995) through regression analysis of laboratory test results of angle braces to be reasonably accurate for channel braces. In this paper, the equation proposed by Teh and Gilbert (2013) is modified to suit an angle brace bolted at one leg, and the modified equation is verified against 61 specimens, each with a unique configuration.

The equations specified in the codes (AISI 2010; SA/SNZ 2005; AISC 2010) and those proposed by de Paula et al. (2008) and Holcomb et al. (1995) are also verified against the present laboratory test results.

\section{Equations for the Net Section Tension Capacity of an Angle Brace}

\section{Code Equations}

Clause 3.2.2(2) of AS/NZS 4600:2005 Cold-Formed Steel Structures (SA/SNZ 2005) specifies the net section tension capacity of a bolted connection in a steel member to be

$$
P_{p}=0.85 k_{t} A_{n} F_{u}
$$

where $A_{n}=$ net area of the section; and $F_{u}=$ material tensile strength of the member. The variable $k_{t}$ in the Eq. (1) represents the net section efficiency factor, which is equal to unity for a connection that ensures uniform stress distribution over the net section.

The clause is adopted from Clause 7.2 of AS 4100-1998 Steel Structures (SA 1998). As explained in the commentary (SA 1999), the explicit coefficient of 0.85 embedded into Eq. (1) "is intended to account for sudden failure by local brittle behaviour at the net section." The apparent reason for the sudden brittle failure not being accounted for using a lower capacity factor (or resistance factor) is that a uniform capacity factor of 0.90 is applied to the net section
Table 1. Net Section Efficiency Factor $k_{t}$ according to AS/NZS 4600:2005

0.75 for unequal angles connected Single angle by short leg, 0.85 otherwise

Double equal angle 1.0

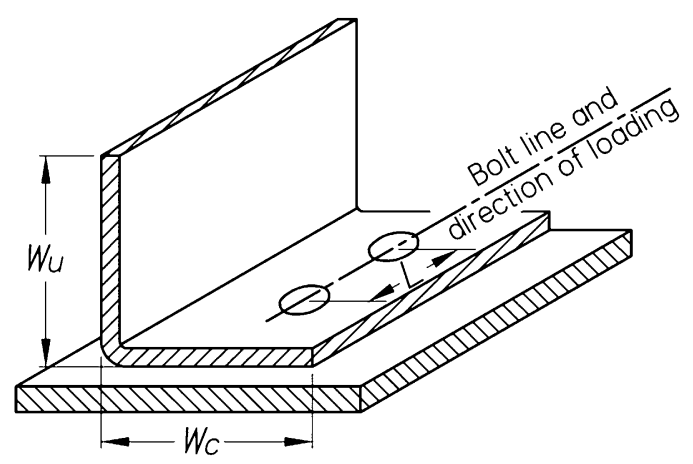

Fig. 2. Definition of geometric variables

fracture mode and the member yielding (over the gross section) mode. The effective capacity factor actually applied to the net section fracture mode is therefore 0.765 .

For the purpose of the present work, Eq. (1) is replaced by

$$
P_{p}=k_{t} A_{n} F_{u}
$$

Table 1 shows the values of $k_{t}$ for angle braces bolted at only one leg specified in Table 3.2 of the Australasian code (SA/SNZ 2005), which depend on how the connection is made.

Section E5.2 of Supplement No. 2 to the North American Specification for the Design of Cold-Formed Steel Structural 
Members 2007 (AISI 2010) specifies the net section tension capacity of an angle brace bolted at one leg to be

$$
P_{p}=A_{n} F_{u} \max [0.4, \min (0.9, \quad 1-1.2 \bar{x} / L)]
$$

in which $\bar{x}=$ distance between the connection interface and the section's centroid in the direction normal to the connection plane; and $L=$ connection length. These variables are defined in Figs. 2 and 3(a).

Eq. (3) was proposed by LaBoube and Yu (1996) based on the laboratory test results of Holcomb et al. (1995) and the equation proposed by Chesson (1959). The original equation is still used in the current AISC specification for structural steel buildings (AISC 2010) with a lower bound shear lag factor equal to the ratio of the connected width to the total width

$$
P_{p}=A_{n} F_{u} \max \left(1-\bar{x} / L, \quad \frac{W_{c}}{W_{c}+W_{u}}\right)
$$

in which the variables $W_{\mathrm{c}}$ and $W_{\mathrm{u}}$ are defined in Fig. 2 .

\section{Equations Presented in the Literature}

Holcomb et al. (1995) proposed the following equation based on nonlinear regression analysis of laboratory test results on specimens with steel grades with measured ratios of tensile strength $F_{u}$ to yield stress $F_{y}$ (i.e., $F_{u} / F_{y}$ ) ranging from 1.45 to 1.56 :

$$
P_{p}=A_{n} F_{u}\left(2.39 \frac{t}{W_{c}+\bar{x}}+0.308\right)\left(\frac{\bar{x}}{L}\right)^{-0.301}
$$

in which $t=$ section thickness. It can be seen that Eq. (5) involves a power term.

Based on regression analysis of laboratory test results, de Paula et al. (2008) proposed the following empirical equation:

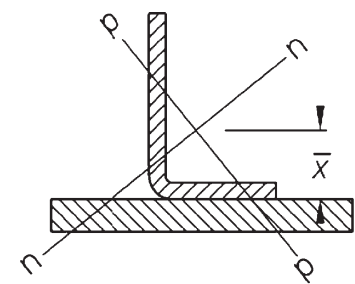

(a) Eccentricity of an angle brace

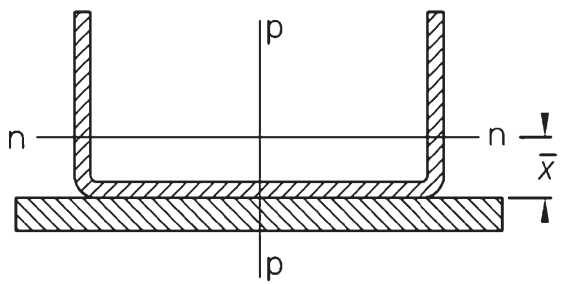

(b) Eccentricity of a channel brace

Fig. 3. Connection eccentricities: (a) eccentricity of an angle brace; (b) eccentricity of a channel brace

$$
\begin{aligned}
& P_{p} \\
& =A_{n} F_{u}\left[1.19-0.26 \bar{x} / L-\frac{\left(0.63 W_{c n}+0.17 W_{u}-0.47 d-1.7 t\right)}{W_{c}}\right]
\end{aligned}
$$

in which

$$
W_{c n}=W_{c}-n_{b} d_{h}
$$

where $n_{b}=$ number of bolts in the considered cross section (which is equal to one for the majority of cold-formed steel angle braces); and $d_{h}=$ bolt hole diameter. The laboratory tests conducted by de Paula et al. (2008) involved specimens composed of relatively ductile steel that has a nominal ratio of tensile strength to yield stress equal to 1.40 .

Kulak and $\mathrm{Wu}$ (1997) proposed the following equation for hotrolled steel angle braces:

$$
P_{p}=A_{n} F_{u}\left(\frac{W_{c n}+\beta W_{u} F_{y} / F_{u}}{W_{c n}+W_{u}}\right)
$$

in which $\beta=0.5$, unless there are four or more bolts per line in the connection, in which case it is equal to 1.0. The equation posits the yielding of the outstanding leg at the fracture of the connected leg. Provided the ductility is sufficient, the lower the ratio of tensile strength $F_{u}$ to yield stress $F_{y}$, the higher the net section efficiency. However, for cold-formed steel, a lower $F_{u} / F_{y}$ value indicates lower ductility as measured by the elongation at the fracture.

\section{Proposed Equation}

Teh and Gilbert (2013) proposed the following equation for determining the net section tension capacity of a cold-formed steelchannel brace bolted at the web:

$$
P_{p}=A_{n} F_{u}\left(\frac{1}{1.1+\frac{W_{f}}{W_{w}+2 W_{f}}+\frac{\bar{x}}{L}}\right)
$$

in which $W_{f}=$ width of the flange; and $W_{w}=$ depth of the web.

Eq. (8) is modified to suit an angle brace

$$
P_{p}=A_{n} F_{u}\left(\frac{1}{1.1+\frac{W_{u}}{W_{c}+W_{u}}+\frac{\bar{x}}{L}}\right)
$$

\begin{tabular}{|c|c|c|c|c|c|c|c|c|}
\hline Nominal thickness $(\mathrm{mm})$ & $t_{\text {base }}(\mathrm{mm})$ & $F_{y}(\mathrm{MPa})$ & $F_{u}(\mathrm{MPa})$ & $F_{u} / F_{y}$ & $\varepsilon_{15}(\%)$ & $\varepsilon_{25}(\%)$ & $\varepsilon_{50}(\%)$ & $\varepsilon_{u o}(\%)$ \\
\hline 1.5 & 1.48 & 605 & 630 & 1.04 & 21.3 & 18.0 & 12.0 & 6.8 \\
\hline 3.0 & 2.95 & 530 & 580 & 1.09 & 29.3 & 22.0 & 15.3 & 8.1 \\
\hline
\end{tabular}

As explained by Teh and Gilbert (2013), the first term in the denominator of Eq. (9) accounts for the in-plane shear lag effect, the second term is the out-of-plane shear lag effect, and the last term is the detrimental bending moment effect caused by the connection eccentricity and the counteracting bending moment effect that increases with the connection length.

Table 2. Average Material Properties 
For angle sections, the variable $\bar{x}$ does not actually represent the connection eccentricity in the same manner as that for channel sections, as illustrated in Fig. 3. In general, an angle brace will be subjected to biaxial bending about the two inclined principal axes.

Eq. (9), which is similar in form to Eq. (8) successfully used by Teh and Gilbert (2013) to predict the net section tension capacity of low ductility channel braces bolted at the web, is simple, continuous, and transparent. There is no artificial lower or upper bound value for

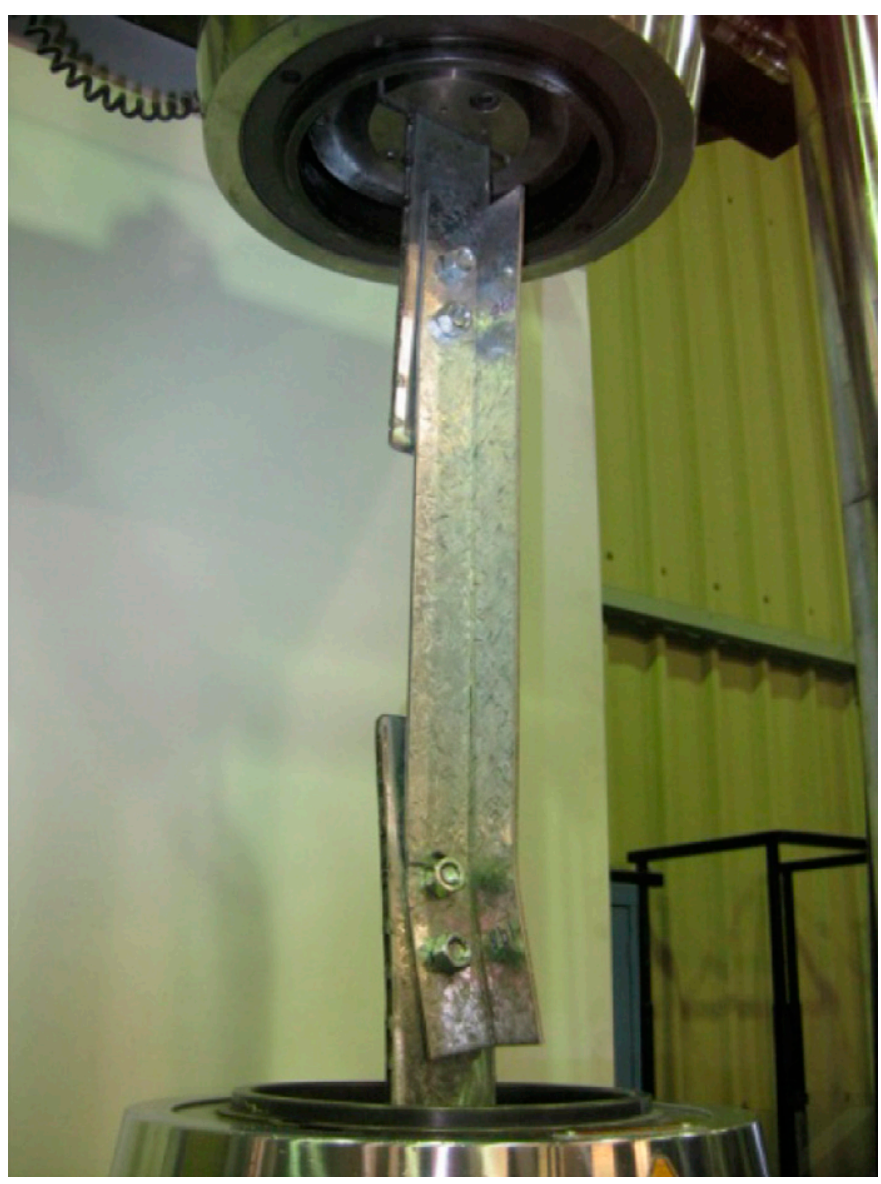

Fig. 4. Tensile testing of a specimen the net section efficiency factor as in Eq. (3) specified by the North American cold-formed steel structures code (AISC 2010), nor discontinuity as in the case of Eq. (4) used in the AISC specification (AISC 2010). The net section efficiency factor embedded in Eq. (9) has a natural upper bound value of 0.909 as the width of the outstanding leg $W_{u}$ approaches zero (in which case the connection eccentricity $\bar{x}$ also approaches zero), which is consistent with the upper bound value of 0.9 specified in Eq. (3).

In Eq. (3), the lower bound value of 0.4 for the net section efficiency factor is reached when the ratio $\bar{x} / L$ is as high as 0.5 . In this case, the natural lower bound value of the proposed Eq. (9) is equal to 0.385 as the width of the connected leg $W_{c}$ approaches zero.

\section{Test Materials}

The G450 sheet steel materials used in the laboratory tests, which have the trade name GALVASPAN, were manufactured and supplied by Bluescope Steel Port Kembla Steelworks, Australia. Two nominal thicknesses were used in the present work: 1.5 and $3.0 \mathrm{~mm}$. The average base metal thicknesses $t_{\text {base }}$, yield stresses $F_{y}$, tensile strengths $F_{u}$, and elongations at fracture over 15-, 25-, and 50-mm gauge lengths $\varepsilon_{15}, \varepsilon_{25}$, and $\varepsilon_{50}$, and uniform elongation outside the fracture $\varepsilon_{u o}$ of the steel materials, as obtained from six $12.5-\mathrm{mm}$ wide tension coupons, are shown in Table 2. Tensile loadings of all coupons and bolted connection specimens are in the direction perpendicular to the rolling direction of the G450 sheet steel. The tension coupon tests were conducted at a constant stroke rate of $1 \mathrm{~mm} / \mathrm{min}$, resulting in a strain rate of about $2 \times 10^{-4}$ per second before necking.

The tensile strengths in the direction perpendicular to the rolling direction of 1.5- and 3.0-mm G450 sheet steels obtained in the present work, rounded to the nearest $5 \mathrm{MPa}$, are 6 and $10 \%$ higher than those obtained by Teh and Hancock (2005) in the rolling direction. Although Teh and Hancock (2005) did not provide the elongations at fracture, it is believed that the rolling direction is associated with higher ductility. The G450 sheet steels used in the present work represent the grades of steel covered by AS/NZS 4600 (SA/SNZ 2005) that are among those with the lowest ductility and for which the nominal tensile strength and yield stress may be fully utilized in structural design calculations (Hancock 2007). The use of such low ductility steel ensures that the proposed design equation is not unsafe for more ductile steels.

Table 3. Results of 3.0-mm Single Equal Angle Specimens

\begin{tabular}{|c|c|c|c|c|c|c|c|c|c|c|c|c|}
\hline \multirow[b]{2}{*}{ Specimen } & \multirow[b]{2}{*}{$d_{h}(\mathrm{~mm})$} & \multirow[b]{2}{*}{$W_{c}(\mathrm{~mm})$} & \multirow[b]{2}{*}{$\bar{x}(\mathrm{~mm})$} & \multirow[b]{2}{*}{$L(\mathrm{~mm})$} & \multirow[b]{2}{*}{$c$} & \multicolumn{7}{|c|}{$P_{t} / P_{p}$} \\
\hline & & & & & & $\begin{array}{l}\text { AS/NZS } \\
\text { [Eq. (2)] }\end{array}$ & $\begin{array}{c}\text { AISI } \\
\text { [Eq. (3)] }\end{array}$ & $\begin{array}{c}\text { AISC } \\
\text { [Eq. (4)] }\end{array}$ & $\begin{array}{l}\text { Holcomb } \\
\text { [Eq. (5)] }\end{array}$ & $\begin{array}{l}\text { de Paula } \\
\text { [Eq. (6)] }\end{array}$ & $\begin{array}{c}\text { Kulak } \\
\text { [Eq. (7)] }\end{array}$ & $\begin{array}{l}\text { Proposed } \\
\text { [Eq. (9)] }\end{array}$ \\
\hline EA2 & 13 & 40 & 10.6 & 40 & 0.56 & 0.66 & 0.82 & 0.76 & 0.85 & 0.72 & 0.82 & 1.04 \\
\hline EA4 & & & & 60 & 0.61 & 0.72 & 0.78 & 0.74 & 0.82 & 0.76 & 0.91 & 1.09 \\
\hline EA6 & & & & 80 & 0.62 & 0.73 & 0.74 & 0.72 & 0.76 & 0.76 & 0.92 & 1.08 \\
\hline EA8 & & 50 & 13.1 & 40 & 0.51 & 0.60 & 0.84 & 0.75 & 0.87 & 0.76 & 0.74 & 0.98 \\
\hline EA10 & & & & 60 & 0.53 & 0.63 & 0.72 & 0.68 & 0.81 & 0.76 & 0.76 & 0.96 \\
\hline EA12 & & & & 80 & 0.60 & 0.71 & 0.75 & 0.72 & 0.85 & 0.84 & 0.87 & 1.06 \\
\hline EA14 & 17 & 60 & 15.6 & 50 & 0.52 & 0.61 & 0.83 & 0.75 & 0.92 & 0.75 & 0.76 & 0.99 \\
\hline EA16 & & & & 75 & 0.60 & 0.70 & 0.80 & 0.75 & 0.94 & 0.84 & 0.87 & 1.08 \\
\hline EA18 & & & & 100 & 0.62 & 0.73 & 0.76 & 0.74 & 0.89 & 0.85 & 0.91 & 1.09 \\
\hline EA20 & & 75 & 19.3 & 50 & 0.48 & 0.57 & 0.90 & 0.79 & 0.95 & 0.81 & 0.69 & 0.95 \\
\hline EA22 & & & & 75 & 0.53 & 0.62 & 0.77 & 0.71 & 0.93 & 0.85 & 0.76 & 0.98 \\
\hline \multirow[t]{3}{*}{ EA24 } & & & & 100 & 0.55 & 0.65 & 0.72 & 0.69 & 0.89 & 0.86 & 0.80 & 0.99 \\
\hline & & & & & Mean & 0.66 & 0.79 & 0.73 & 0.87 & 0.80 & 0.82 & 1.03 \\
\hline & & & & & $\mathrm{COV}$ & 0.086 & 0.068 & 0.042 & 0.066 & 0.062 & 0.094 & 0.052 \\
\hline
\end{tabular}

Note: $\mathrm{COV}=$ coefficient of variation. 


\section{Specimen Configurations and Test Arrangements}

The configurations tested in the laboratory are single equal angle, single angle bolted at the wider leg, single angle bolted at the narrow leg, double angles, and alternate angles, as depicted in Fig. 1. The

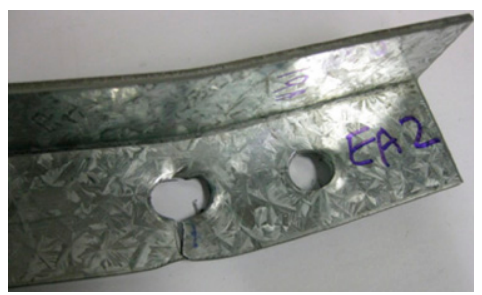

(a) $3.0 \mathrm{~mm}$ specimen

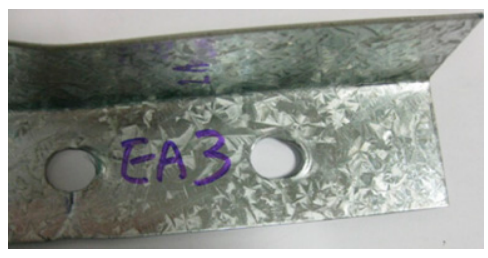

(b) $1.5 \mathrm{~mm}$ specimen

Fig. 5. Net section fracture of single equal angle specimens: (a) 3.0-mm specimens; (b) 1.5-mm specimens leg widths range from 40 to $100 \mathrm{~mm}$, with $12-\mathrm{mm}$ bolts being used in legs up to $50 \mathrm{~mm}$ wide, and 16-mm bolts in wider legs to avoid the possibility of bearing failures. The bolt holes are nominally $1 \mathrm{~mm}$ larger than the relevant bolt diameters and are situated centrally in a leg, as illustrated in Fig. 1.

Cold-formed steel angle braces connected with one bolt at one leg normally fail by bearing (AISI 2007a). Such connections are often more prone to the shear-out or block-shear failure mode, the mechanisms of which were elaborated by Teh and Clements (2012a). Therefore, net section fracture does not have a practical significance for such connections.

All the present test specimens had two bolts aligned parallel to the direction of loading, as depicted in Fig. 2. The bolt spacings were at least three times the bolt diameter, as required by the codes (SA/SNZ 2005; AISI 2007b). The connection lengths ranged from 40 to $80 \mathrm{~mm}$ for the specimens with $12-\mathrm{mm}$ bolts and from 50 to $100 \mathrm{~mm}$ for those with 16-mm bolts.

The angle specimens were connected to 6-mm-thick plates, which are significantly more flexible in bending than those used by other researchers (Holcomb et al. 1995; de Paula et al. 2008). It was thought that thicker plates might lead to higher net section tension capacities of the braces because of the greater resistance to the bending caused by connection eccentricities.

The bolts were tightened by hand only to avoid friction from contributing to the tension capacities of the specimens. Washers were used for the specimens where bolt punching failure was suspected to be likely if washers were not used (i.e., angles with 100-mm-wide

Table 4. Results of 1.5-mm Single Equal Angle Specimens

\begin{tabular}{|c|c|c|c|c|c|c|c|c|c|c|c|c|}
\hline \multirow[b]{2}{*}{ Specimen } & \multirow[b]{2}{*}{$d_{h}(\mathrm{~mm})$} & \multirow[b]{2}{*}{$W_{c}(\mathrm{~mm})$} & \multirow[b]{2}{*}{$\bar{x}(\mathrm{~mm})$} & \multirow[b]{2}{*}{$L(\mathrm{~mm})$} & \multirow[b]{2}{*}{$c$} & \multicolumn{7}{|c|}{$P_{t} / P_{p}$} \\
\hline & & & & & & $\begin{array}{l}\text { AS/NZS } \\
{[\text { Eq. (2)] }}\end{array}$ & $\begin{array}{c}\text { AISI } \\
{[\text { Eq. (3)] }}\end{array}$ & $\begin{array}{c}\text { AISC } \\
{[\text { Eq. (4)] }}\end{array}$ & $\begin{array}{l}\text { Holcomb } \\
{[\text { Eq. (5)] }}\end{array}$ & $\begin{array}{l}\text { de Paula } \\
\text { [Eq. (6)] }\end{array}$ & $\begin{array}{c}\text { Kulak } \\
{[\text { Eq. (7)] }}\end{array}$ & $\begin{array}{c}\text { Proposed } \\
\text { [Eq. (9)] }\end{array}$ \\
\hline EA1 & 13 & 40 & 10.7 & 40 & 0.53 & 0.63 & 0.79 & 0.73 & 0.95 & 0.73 & 0.77 & 1.00 \\
\hline EA3 & & & & 60 & 0.59 & 0.69 & 0.75 & 0.72 & 0.93 & 0.78 & 0.85 & 1.05 \\
\hline EA5 & & & & 80 & 0.59 & 0.69 & 0.70 & 0.68 & 0.85 & 0.77 & 0.86 & 1.03 \\
\hline EA7 & & 50 & 13.2 & 40 & 0.47 & 0.56 & 0.79 & 0.71 & 0.94 & 0.75 & 0.67 & 0.92 \\
\hline EA9 & & & & 60 & 0.51 & 0.60 & 0.70 & 0.66 & 0.90 & 0.78 & 0.73 & 0.93 \\
\hline EA11 & & & & 80 & 0.53 & 0.63 & 0.67 & 0.64 & 0.86 & 0.79 & 0.76 & 0.94 \\
\hline EA13 & 17 & 60 & 15.7 & 50 & 0.52 & 0.61 & 0.83 & 0.76 & 1.03 & 0.79 & 0.74 & 0.99 \\
\hline EA15 & & & & 75 & 0.54 & 0.63 & 0.72 & 0.68 & 0.95 & 0.80 & 0.77 & 0.97 \\
\hline \multirow[t]{3}{*}{ EA17 } & & & & 100 & 0.56 & 0.66 & 0.69 & 0.66 & 0.90 & 0.80 & 0.80 & 0.98 \\
\hline & & & & & Mean & 0.63 & 0.74 & 0.69 & 0.92 & 0.78 & 0.77 & 0.98 \\
\hline & & & & & $\mathrm{COV}$ & 0.067 & 0.075 & 0.054 & 0.061 & 0.030 & 0.076 & 0.044 \\
\hline
\end{tabular}

Note: $\mathrm{COV}=$ coefficient of variation.

Table 5. Results of 3.0-mm Double Equal Angle Specimens

\begin{tabular}{|c|c|c|c|c|c|c|c|c|c|c|c|c|}
\hline \multirow[b]{2}{*}{ Specimen } & \multirow[b]{2}{*}{$d_{h}(\mathrm{~mm})$} & \multirow[b]{2}{*}{$W_{c}(\mathrm{~mm})$} & \multirow[b]{2}{*}{$\bar{x}(\mathrm{~mm})$} & \multirow[b]{2}{*}{$L(\mathrm{~mm})$} & \multirow[b]{2}{*}{$c$} & \multicolumn{7}{|c|}{$P_{t} / P_{p}$} \\
\hline & & & & & & $\begin{array}{l}\text { AS/NZS } \\
\text { [Eq. (2)] }\end{array}$ & $\begin{array}{c}\text { AISI } \\
\text { [Eq. (3)] }\end{array}$ & $\begin{array}{c}\text { AISC } \\
\text { [Eq. (4)] }\end{array}$ & $\begin{array}{l}\text { Holcomb } \\
\text { [Eq. (5)] }\end{array}$ & $\begin{array}{l}\text { de Paula } \\
\text { [Eq. (6)] }\end{array}$ & $\begin{array}{c}\text { Kulak } \\
\text { [Eq. (7)] }\end{array}$ & $\begin{array}{l}\text { Proposed } \\
\text { [Eq. (9)] }\end{array}$ \\
\hline DEA1 & 13 & 40 & 10.6 & 40 & 0.51 & 0.51 & 0.75 & 0.70 & 0.77 & 0.65 & 0.76 & 0.96 \\
\hline DEA2 & & & & 60 & 0.58 & 0.58 & 0.74 & 0.71 & 0.78 & 0.73 & 0.86 & 1.04 \\
\hline DEA3 & & & & 80 & 0.63 & 0.63 & 0.75 & 0.73 & 0.77 & 0.77 & 0.93 & 1.09 \\
\hline DEA4 & & 50 & 13.1 & 40 & 0.50 & 0.50 & 0.82 & 0.74 & 0.85 & 0.73 & 0.71 & 0.95 \\
\hline DEA5 & & & & 60 & 0.51 & 0.51 & 0.69 & 0.65 & 0.77 & 0.72 & 0.74 & 0.92 \\
\hline DEA6 & & & & 80 & 0.52 & 0.52 & 0.65 & 0.63 & 0.72 & 0.72 & 0.77 & 0.93 \\
\hline DEA7 & 17 & 60 & 15.6 & 50 & 0.51 & 0.51 & 0.82 & 0.75 & 0.91 & 0.75 & 0.74 & 0.98 \\
\hline DEA8 & & & & 75 & 0.52 & 0.52 & 0.69 & 0.66 & 0.81 & 0.72 & 0.75 & 0.93 \\
\hline \multirow[t]{3}{*}{ DEA9 } & & & & 100 & 0.59 & 0.59 & 0.72 & 0.70 & 0.85 & 0.80 & 0.84 & 1.02 \\
\hline & & & & & Mean & 0.54 & 0.74 & 0.69 & 0.80 & 0.73 & 0.79 & 0.98 \\
\hline & & & & & $\mathrm{COV}$ & 0.087 & 0.077 & 0.060 & 0.071 & 0.057 & 0.091 & 0.059 \\
\hline
\end{tabular}

Note: $\mathrm{COV}=$ coefficient of variation. 


\begin{tabular}{|c|c|c|c|c|c|c|c|c|c|c|c|c|}
\hline \multirow[b]{2}{*}{ Specimen } & \multirow[b]{2}{*}{$d_{h}(\mathrm{~mm})$} & \multirow[b]{2}{*}{$W_{c}(\mathrm{~mm})$} & \multirow[b]{2}{*}{$\bar{x}(\mathrm{~mm})$} & \multirow[b]{2}{*}{$L(\mathrm{~mm})$} & \multirow[b]{2}{*}{$c$} & \multicolumn{7}{|c|}{$P_{t} / P_{p}$} \\
\hline & & & & & & $\begin{array}{l}\text { AS/NZS } \\
\text { [Eq. (2)] }\end{array}$ & $\begin{array}{c}\text { AISI } \\
\text { [Eq. (3)] }\end{array}$ & $\begin{array}{c}\text { AISC } \\
\text { [Eq. (4)] }\end{array}$ & $\begin{array}{l}\text { Holcomb } \\
\text { [Eq. (5)] }\end{array}$ & $\begin{array}{l}\text { de Paula } \\
\text { [Eq. (6)] }\end{array}$ & $\begin{array}{c}\text { Kulak } \\
\text { [Eq. (7)] }\end{array}$ & $\begin{array}{l}\text { Proposed } \\
\text { [Eq. (9)] }\end{array}$ \\
\hline AEA1 & 13 & 40 & 10.6 & 40 & 0.58 & 0.68 & 0.84 & 0.78 & 0.88 & 0.75 & 0.84 & 1.07 \\
\hline $\mathrm{AEA} 2^{\mathrm{a}}$ & & 50 & 13.1 & 80 & 0.56 & 0.66 & 0.70 & 0.67 & 0.79 & 0.79 & 0.81 & 0.99 \\
\hline AEA3 & 17 & 60 & 15.6 & 50 & 0.52 & 0.62 & 0.84 & 0.76 & 0.93 & 0.76 & 0.76 & 1.00 \\
\hline AEA4 & & & & 75 & 0.58 & 0.68 & 0.77 & 0.73 & 0.91 & 0.81 & 0.84 & 1.04 \\
\hline \multirow[t]{3}{*}{ AEA5 } & & & & 100 & 0.62 & 0.73 & 0.76 & 0.73 & 0.89 & 0.85 & 0.90 & 1.08 \\
\hline & & & & & Mean & 0.67 & 0.78 & 0.74 & 0.88 & 0.79 & 0.83 & 1.04 \\
\hline & & & & & $\mathrm{COV}$ & 0.061 & 0.077 & 0.058 & 0.062 & 0.053 & 0.061 & 0.042 \\
\hline
\end{tabular}

Note: $\mathrm{COV}=$ coefficient of variation.

${ }^{\mathrm{a} C o n n e c t i o n}$ plate failed.

connected leg and 50-mm-wide outstanding leg). Although washers did not affect the tension capacity, they were shown by Teh and Clements (2012b) to be very effective in preventing bolt punching failure to achieve the desired net section tension fracture mode.

The bolted connection specimens were tested to failure using an Instron 8033 universal testing machine (Fig. 4) at a stroke rate of $1 \mathrm{~mm} / \mathrm{min}$, which coincides with that used for the tension coupon tests.

\section{Experimental Test Results and Discussions}

In calculating the net section tension capacity $P_{p}$ of a specimen predicted by design equations, the measured values of the geometric dimensions, such as the base metal thickness, the leg widths, the bolt hole diameter, and the connection length, are used. However, for ease of comparisons, only the nominal values are shown in all the tables.

\section{Single Equal Angle Specimens (EA Series)}

Table 3 lists the relevant geometric dimensions and the test results of the 3.0-mm-thick single equal angle specimens. An empty cell in Table 3 indicates that the data in the cell above it apply. The variable $c$ denotes the test net section efficiency factor, defined as the ratio of ultimate test load to tension capacity computed by assuming uniform stress distribution.

Table 3 shows the ratios of the ultimate test load $P_{t}$ to the tension capacity $P_{p}$ predicted by Eqs. (2)-(7) and (9). All the specimens failed in the net section fracture mode, as shown in Fig. 5(a) for Specimen EA2.

It is seen from Table 3 that Eqs. (2)-(7) significantly overestimate the net section tension capacities of the present specimens, which were composed of low ductility sheet steel. In contrast, Eq. (9) estimates the failure loads with reasonable accuracy.

Table 4 lists the relevant geometric dimensions and the test results of the 1.5-mm specimens that failed in the net section fracture mode, as shown in Fig. 5(b) for Specimen EA3.

As with the 3.0-mm-thick specimens, Eqs. (2)-(7) significantly overestimate the net section tension capacities of the $1.5-\mathrm{mm}$ specimens. Eq. (9) again estimates the failure loads with reasonable accuracy, although it overestimates some by more than $5 \%$.

The 1.5-mm-thick EA specimens with 75-mm-wide legs failed in bearing, and were therefore not included in Table 4. Teh and Gilbert (2012) noted that bolted connections in 1.5-mm sheet steel were more prone to bearing failure compared with those in 3.0-mm sheet steel.

\section{Double Equal Angle Specimens (DEA Series)}

Table 5 lists the relevant geometric dimensions and the test results of the 3.0-mm-thick double equal angle specimens. All the specimens

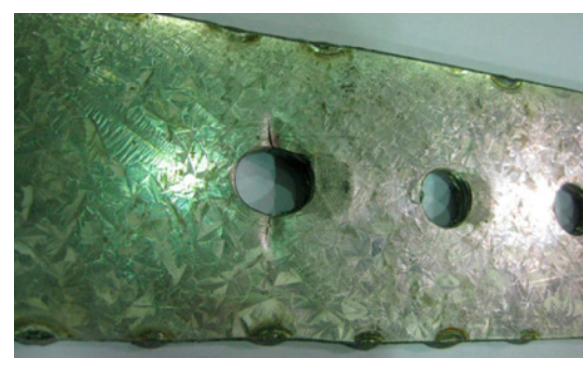

(a) Fracture of a connection plate

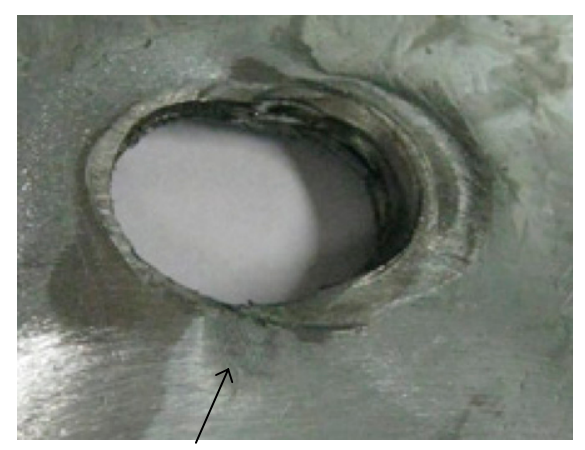

(b) Crack line in AEA2

Fig. 6. Fracture of connection plate for Specimen AEA2: (a) fracture of a connection plate; (b) crack line in AEA2

failed in the net section fracture mode in the same manner as the single equal angle specimens shown in Fig. 5.

Despite the intuition that the double angle specimens (which were symmetric about the connection plate) would be stronger than the comparable single angle specimens, the results in Tables 3 and 5 show that, on average, the single angle specimens were stronger by $5 \%$. The present finding is consistent with that of Kulak and $\mathrm{Wu}$ (1997) for hot-rolled steel specimens.

Eq. (9) remains reasonably accurate for the double angle specimens, whereas Eqs. (2)-(7) overestimate the net section tension capacities of the double angle specimens.

\section{Alternate Equal Angle Specimens (AEA Series)}

Table 6 lists the relevant geometric dimensions and the test results of the 3.0-mm-thick alternate equal angle specimens. All the specimens failed in the net section fracture mode in the same manner as the single equal angle specimens shown in Fig. 5.

Table 3.2 of the Australasian code (SA/SNZ 2005) does not specify the value of $k_{t}$ for this configuration, which in this work is assumed to be 0.85 . 
Table 7. Results of 3.0-mm Unequal Angle Specimens Bolted at the Wider Leg (All 17-mm Bolt Holes)

\begin{tabular}{|c|c|c|c|c|c|c|c|c|c|c|c|c|}
\hline \multirow[b]{2}{*}{ Specimen } & \multirow[b]{2}{*}{$W_{c}(\mathrm{~mm})$} & \multirow[b]{2}{*}{$W_{u}(\mathrm{~mm})$} & \multirow[b]{2}{*}{$\bar{x}(\mathrm{~mm})$} & \multirow[b]{2}{*}{$L(\mathrm{~mm})$} & \multirow[b]{2}{*}{$c$} & \multicolumn{7}{|c|}{$P_{t} / P_{p}$} \\
\hline & & & & & & $\begin{array}{l}\text { AS/NZS } \\
\text { [Eq. (2)] }\end{array}$ & $\begin{array}{c}\text { AISI } \\
\text { [Eq. (3)] }\end{array}$ & $\begin{array}{c}\text { AISC } \\
\text { [Eq. (4)] }\end{array}$ & $\begin{array}{l}\text { Holcomb } \\
\text { [Eq. (5)] }\end{array}$ & $\begin{array}{l}\text { de Paula } \\
\text { [Eq. (6)] }\end{array}$ & $\begin{array}{c}\text { Kulak } \\
\text { [Eq. (7)] }\end{array}$ & $\begin{array}{l}\text { Proposed } \\
\text { [Eq. (9)] }\end{array}$ \\
\hline UAW1 & 60 & 40 & 7.80 & 50 & 0.62 & 0.72 & 0.76 & 0.73 & 0.87 & 0.80 & 0.82 & 1.02 \\
\hline UAW2 & & & & 75 & 0.67 & 0.79 & 0.76 & 0.74 & 0.83 & 0.84 & 0.90 & 1.07 \\
\hline UAW3 & & & & 100 & 0.69 & 0.82 & 0.77 & 0.75 & 0.79 & 0.87 & 0.93 & 1.09 \\
\hline UAW4 & 80 & & 6.45 & 50 & 0.66 & 0.77 & 0.78 & 0.75 & 0.92 & 0.91 & 0.83 & 1.03 \\
\hline UAW5 & & & & 75 & 0.70 & 0.82 & 0.78 & 0.76 & 0.87 & 0.95 & 0.89 & 1.07 \\
\hline UAW6 & & & & 100 & 0.72 & 0.85 & 0.80 & 0.77 & 0.82 & 0.97 & 0.91 & 1.08 \\
\hline UAW7 & 75 & 50 & 9.80 & 50 & 0.54 & 0.63 & 0.70 & 0.67 & 0.85 & 0.78 & 0.72 & 0.92 \\
\hline UAW8 & & & & 75 & 0.62 & 0.73 & 0.74 & 0.72 & 0.87 & 0.87 & 0.83 & 1.02 \\
\hline UAW9 & & & & 100 & 0.63 & 0.74 & 0.71 & 0.70 & 0.81 & 0.87 & 0.84 & 1.01 \\
\hline \multirow[t]{3}{*}{ UAW11 } & 100 & & 8.11 & 75 & 0.62 & 0.73 & 0.71 & 0.69 & 0.85 & 0.92 & 0.78 & 0.96 \\
\hline & & & & & Mean & 0.76 & 0.75 & 0.73 & 0.85 & 0.88 & 0.85 & 1.03 \\
\hline & & & & & $\mathrm{COV}$ & 0.082 & 0.044 & 0.046 & 0.044 & 0.070 & 0.075 & 0.053 \\
\hline
\end{tabular}

Note: $\mathrm{COV}=$ coefficient of variation.

On average, the alternate specimens were $6 \%$ stronger than the double specimens in Table 5 and were as strong as the single angle specimens in Table 3. It should be noted that Specimen AEA2 did not fracture, because the ultimate test load was caused by the fracture of a connection plate at the critical bolt hole, as shown in Fig. 6(a). However, the result has been included in the Table 5 because it is believed that the specimen was close to its ultimate tension capacity, as evidenced from the necking and very fine crack line shown in Fig. 6(b).

It is noteworthy that, for most of the present single, double, and alternate equal angle specimens, Eq. (7) proposed by Kulak and $\mathrm{Wu}$ (1997) for hot-rolled steel angles led to professional factors $P_{t} / P_{p}$ closer to unity than Eqs. (3) and (6), which are intended for cold-formed steel angles. This outcome would have been accentuated if the ratios of tensile strength $F_{u}$ to yield stress $F_{y}$ were higher than those shown in Table 2, because Eq. (7) would then give even lower net section efficiency factors compared with Eqs. (3) and (6).

In any case, Eq. (9) remains reasonably accurate for the alternate angle specimens.

\section{Unequal Angle Specimens Bolted at the Wider Leg (UAW Series)}

Table 7 lists the relevant geometric dimensions and the test results of the 3.0-mm-thick unequal angle specimens connected with $16-\mathrm{mm}$ bolts at the wider leg that failed in the net section fracture mode, as shown in Fig. 7(a) for Specimen UAW2. An empty cell in Table 7 indicates that the data in the cell above it apply.

Specimen UAW10 (not included in Table 7) had the same dimensions as Specimen UAW11, except for the connection length, which was $50 \mathrm{~mm}$ in the former. However, Specimen UAW10, which did not have washers, failed in the bolt punching/ bearing mode as evident in Fig. 8(a). Washers were used for specimen UAW12 (not included in Table 7), which had a connection length of $100 \mathrm{~mm}$. This specimen failed in bearing, as shown in Fig. 8(b).

Table 8 lists the geometric dimensions and the test results of the 1.5-mm-thick specimens that failed in net section fracture, as shown in Fig. 7(b) for specimen UAW13. Tables 7 and 8 show that, as with the preceding configurations, Eqs. (2)-(7) significantly overestimate the net section tension capacities of the unequal angle specimens bolted at the wider leg. Eq. (9) is reasonably accurate for both 3.0and $1.5-\mathrm{mm}$ specimens.

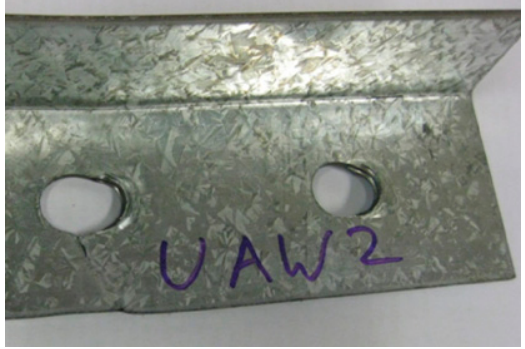

(a) $3.0 \mathrm{~mm}$ specimen

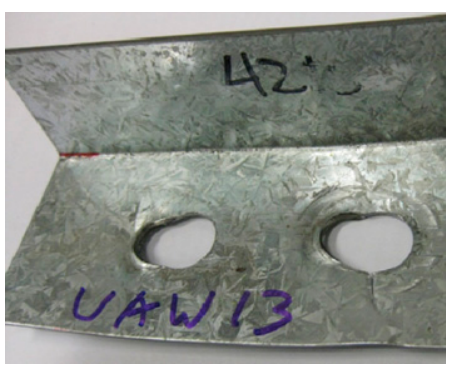

(b) $1.5 \mathrm{~mm}$ specimen

Fig. 7. Net section fracture of unequal angle specimens bolted at the wider leg: (a) 3.0-mm specimens; (b) 1.5-mm specimens

\section{Unequal Angle Specimens Bolted at the Narrow Leg (UAN Series)}

Table 9 lists the relevant geometric dimensions and the test results of the 3.0-mm-thick unequal angle specimens bolted at the narrow leg with $12-\mathrm{mm}$ bolts. All the specimens failed in the net section fracture mode, as shown in Fig. 9 for Specimen UAN10.

Eq. (9) overestimates the capacities of the unequal angle specimens bolted at the narrow leg. However, the proposed equation remains more accurate than all the other equations, with an average professional factor $P_{t} / P_{p}$ of 0.93 and a coefficient of variation equal to 0.073 .

Except for the unequal angle specimens bolted at the narrow leg, Eq. (5), as proposed by Holcomb et al. (1995), led to considerably more accurate estimates compared with Eq. (3) proposed by LaBoube and $\mathrm{Yu}$ (1996), although both equations were derived based on the same laboratory test results obtained by Holcomb et al. 


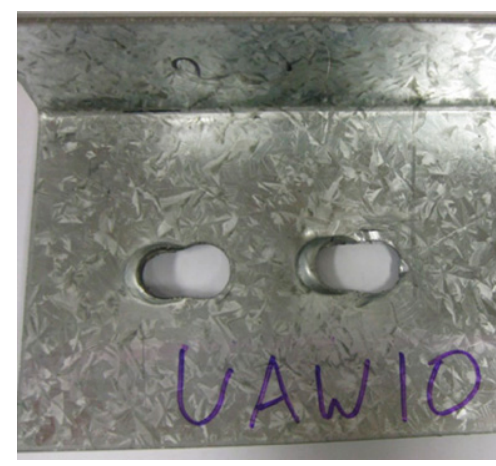

(a) $L=50 \mathrm{~mm}$, no washers

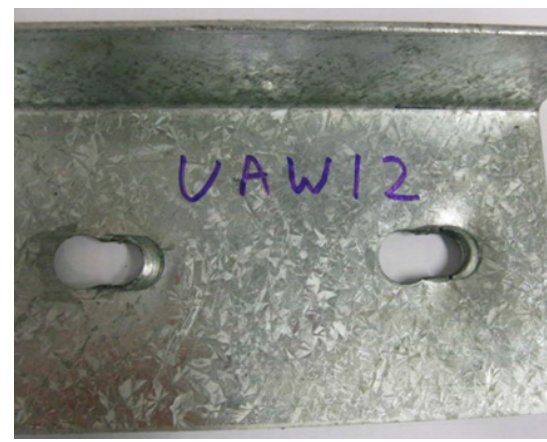

(b) $L=100 \mathrm{~mm}$, with washers

Fig. 8. Bolt punching/bearing and bearing failures of $100 \times 50-\mathrm{mm}$ angles: (a) $L=50 \mathrm{~mm}$, no washers; (b) $L=100 \mathrm{~mm}$, with washers
Resistance Factor (or Capacity Reduction Factor)

Excluding the unequal angle specimens bolted at the narrow leg, the overall professional factor $P_{t} / P_{p}$ given by Eq. (9) for the 49 specimens is 0.99 , with a coefficient of variation of 0.064 . It therefore seems reasonable to treat the single equal angle, double equal angle, alternate equal angle, and single unequal angle specimens bolted at the wider leg as one population for the purpose of determining a uniform resistance factor for these configurations.

Section F1.1 of the North American specification (AISI 2007b) specifies that the resistance factor $\phi$ of a design equation is determined as follows:

$$
\phi=C_{\phi}\left(M_{m} F_{m} P_{m}\right) e^{p}
$$

where $C_{\phi}=$ calibration coefficient equal to 1.52 in the case of the load and resistance factor design (LRFD); $M_{m}=$ mean value of the material factor equal to 1.10 according to Table F1 of the North American specification (AISI 2007b); $F_{m}=$ mean value of the fabrication factor equal to 1.00 ; and $P_{m}=$ mean value of the professional factor equal to 0.99 as stated in the preceding text.

The power $p$ of the natural logarithmic base $e$ in Eq. (10) is

$$
p=-\beta_{0} \sqrt{V_{M}^{2}+V_{F}^{2}+C_{p} V_{P}^{2}+V_{Q}^{2}}
$$

where $V_{M}=$ coefficient of variation of the material factor equal to 0.08 in the present case; $V_{F}=$ coefficient of variation of the fabrication factor equal to $0.05 ; V_{P}=$ coefficient of variation of the

\begin{tabular}{|c|c|c|c|c|c|c|c|c|c|c|c|c|}
\hline \multirow[b]{2}{*}{ Specimen } & \multirow[b]{2}{*}{$W_{c}(\mathrm{~mm})$} & \multirow[b]{2}{*}{$W_{u}(\mathrm{~mm})$} & \multirow[b]{2}{*}{$\bar{x}(\mathrm{~mm})$} & \multirow[b]{2}{*}{$L(\mathrm{~mm})$} & \multirow[b]{2}{*}{$c$} & \multicolumn{7}{|c|}{$P_{t} / P_{p}$} \\
\hline & & & & & & $\begin{array}{l}\text { AS/NZS } \\
{[\text { Eq. (2)] }}\end{array}$ & $\begin{array}{c}\text { AISI } \\
\text { [Eq. (3)] }\end{array}$ & $\begin{array}{c}\text { AISC } \\
{[\mathrm{Eq} .(4)]}\end{array}$ & $\begin{array}{r}\text { Holcomb } \\
{[\text { Eq. (5)] }}\end{array}$ & $\begin{array}{l}\text { de Paula } \\
\text { [Eq. (6)] }\end{array}$ & $\begin{array}{c}\text { Kulak } \\
\text { [Eq. (7)] }\end{array}$ & $\begin{array}{l}\text { Proposed } \\
\text { [Eq. (9)] }\end{array}$ \\
\hline UAW13 & 60 & 40 & 7.92 & 50 & 0.57 & 0.67 & 0.71 & 0.68 & 0.92 & 0.77 & 0.77 & 0.95 \\
\hline UAW16 & 80 & & 6.57 & & 0.64 & 0.75 & 0.76 & 0.74 & 1.00 & 0.92 & 0.80 & 1.00 \\
\hline UAW17 & & & & 75 & 0.64 & 0.75 & 0.72 & 0.70 & 0.89 & 0.91 & 0.81 & 0.98 \\
\hline \multirow[t]{3}{*}{ UAW19 } & 75 & 50 & 9.92 & 50 & 0.55 & 0.64 & 0.72 & 0.68 & 0.96 & 0.82 & 0.73 & 0.94 \\
\hline & & & & & Mean & 0.71 & 0.72 & 0.70 & 0.94 & 0.85 & 0.78 & 0.97 \\
\hline & & & & & $\mathrm{COV}$ & 0.081 & 0.033 & 0.038 & 0.053 & 0.084 & 0.046 & 0.029 \\
\hline
\end{tabular}

Table 8. Results of 1.5-mm Unequal Angle Specimens Bolted at the Wider Leg (All 17-mm Bolt Holes)

Note: $\mathrm{COV}=$ coefficient of variation.

\begin{tabular}{|c|c|c|c|c|c|c|c|c|c|c|c|c|}
\hline \multirow[b]{2}{*}{ Specimen } & \multirow[b]{2}{*}{$W_{c}(\mathrm{~mm})$} & \multirow[b]{2}{*}{$W_{u}(\mathrm{~mm})$} & \multirow[b]{2}{*}{$\bar{x}(\mathrm{~mm})$} & \multirow[b]{2}{*}{$L(\mathrm{~mm})$} & \multirow[b]{2}{*}{$c$} & \multicolumn{7}{|c|}{$P_{t} / P_{p}$} \\
\hline & & & & & & $\begin{array}{l}\text { AS/NZS } \\
{[\text { Eq. (2)] }}\end{array}$ & $\begin{array}{c}\text { AISI } \\
{[\mathrm{Eq} .(3)]}\end{array}$ & $\begin{array}{c}\text { AISC } \\
{[\text { Eq. (4)] }}\end{array}$ & $\begin{array}{l}\text { Holcomb } \\
{[\text { Eq. (5)] }}\end{array}$ & $\begin{array}{l}\text { de Paula } \\
{[\text { Eq. (6)] }}\end{array}$ & $\begin{array}{c}\text { Kulak } \\
\text { [Eq. (7)] }\end{array}$ & $\begin{array}{l}\text { Proposed } \\
\text { [Eq. (9)] }\end{array}$ \\
\hline UAN1 & 40 & 60 & 19.5 & 40 & 0.42 & 0.56 & 1.01 & 0.82 & 0.80 & 0.64 & 0.66 & 0.91 \\
\hline UAN2 & & & & 60 & 0.52 & 0.70 & 0.86 & 0.77 & 0.88 & 0.77 & 0.82 & 1.05 \\
\hline UAN3 & & & & 80 & 0.55 & 0.73 & 0.78 & 0.73 & 0.85 & 0.78 & 0.87 & 1.06 \\
\hline UAN4 & & 80 & 28.3 & 40 & 0.37 & 0.49 & 0.92 & 1.09 & 0.81 & 0.73 & 0.62 & 0.91 \\
\hline UAN5 & & & & 60 & 0.43 & 0.58 & 1.00 & 0.82 & 0.85 & 0.76 & 0.72 & 0.96 \\
\hline UAN6 & & & & 80 & 0.43 & 0.58 & 0.76 & 0.67 & 0.78 & 0.74 & 0.73 & 0.92 \\
\hline UAN7 & 50 & 75 & 24.0 & 40 & 0.41 & 0.54 & 1.02 & 1.00 & 0.88 & 0.77 & 0.63 & 0.94 \\
\hline UAN8 & & & & 60 & 0.46 & 0.61 & 0.88 & 0.76 & 0.87 & 0.79 & 0.71 & 0.95 \\
\hline UAN9 & & & & 80 & 0.46 & 0.62 & 0.73 & 0.66 & 0.81 & 0.76 & 0.72 & 0.92 \\
\hline UAN10 & & 100 & 34.9 & 40 & 0.33 & 0.43 & 0.81 & 0.95 & 0.80 & 0.88 & 0.53 & 0.86 \\
\hline UAN11 & & & & 60 & 0.37 & 0.49 & 0.91 & 0.87 & 0.79 & 0.80 & 0.60 & 0.86 \\
\hline \multirow[t]{3}{*}{ UAN12 } & & & & 80 & 0.39 & 0.52 & 0.82 & 0.69 & 0.78 & 0.79 & 0.64 & 0.85 \\
\hline & & & & & Mean & 0.57 & 0.87 & 0.82 & 0.82 & 0.77 & 0.69 & 0.93 \\
\hline & & & & & $\mathrm{COV}$ & 0.150 & 0.115 & 0.166 & 0.045 & 0.072 & 0.135 & 0.073 \\
\hline
\end{tabular}

Table 9. Results of 3.0-mm Unequal Angle Specimens Bolted at the Narrow Leg (All 13-mm Bolt Holes)

Note: $\mathrm{COV}=$ coefficient of variation. 


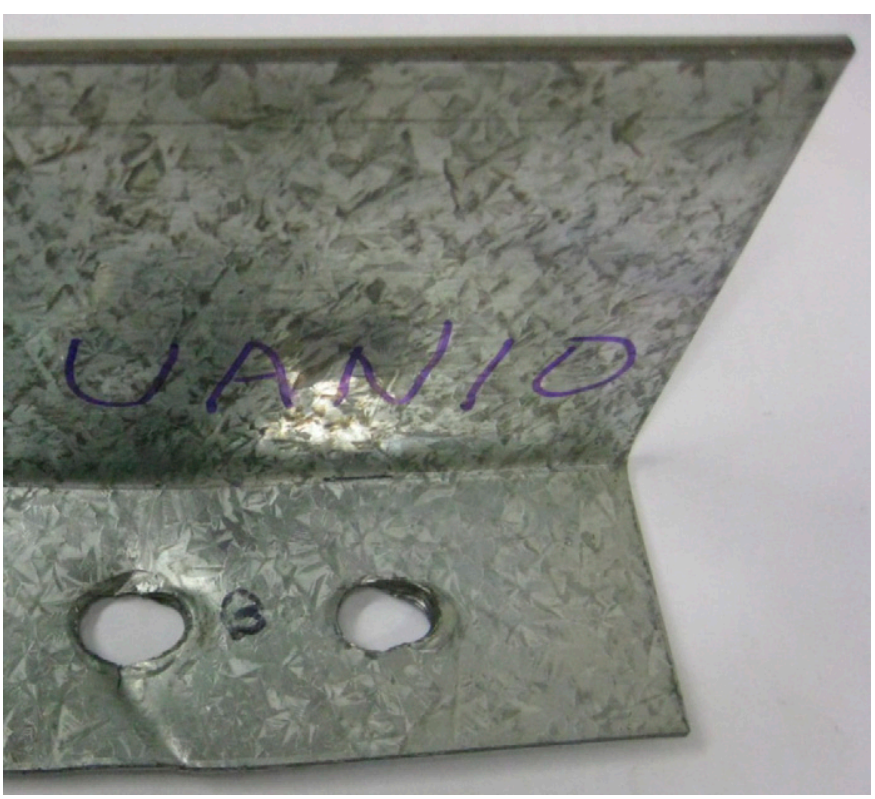

Fig. 9. Net section fracture of an unequal angle specimen bolted at the narrow leg

professional factor equal to 0.065 (being the minimum value specified in Section F1.1 of the specification); $C_{p}=$ correction factor equal to 1.06 as computed from the relevant equation given in Section F1.1; and $V_{Q}=$ coefficient of variation of load effects equal to 0.21 as specified in Section F1.1 (AISI 2007b).

It was found that to achieve the target reliability index $\beta_{0}$ of 3.5 in the LRFD, Eq. (10) yields a resistance factor of 0.72 . A resistance factor $\phi=0.70$ (rounded down to the nearest 0.05 ) in conjunction with Eq. (9) is therefore recommended for the LRFD approach for determining the net section tension capacity of a bolted angle brace other than a single or double unequal angle bolted at the narrow leg.

For the single unequal angle brace specimens bolted at the narrow leg, Eq. (10) yields a resistance factor of 0.66. A resistance factor equal to 0.65 in conjunction with Eq. (9) is recommended for unequal angle braces bolted at the narrow leg, whether single or double.

\section{Conclusions}

A design equation resulting from a modification of one intended for channel braces bolted at the web has been proposed for angle braces bolted at one leg. The proposed equation, which is simple in form, has been shown to be significantly more accurate than the code equations and those presented in the literature for determining the net section tension capacities of low ductility braces composed of single equal angle, double equal angles, alternate equal angles, single unequal angle bolted at the wider leg, and single unequal angle bolted at the narrow leg that were tested in the present work. The steel materials used in the experiment are among those with the lowest ductility to ensure that the proposed equation and the corresponding capacity factor are conservative for all steel grades accepted by the design specifications.

The proposed equation yields reasonably accurate and consistent results across all configurations, except for single unequal angle specimens bolted at the narrow leg, for which the capacities are overestimated.

It is recommended that, for all configurations other than single unequal angle braces bolted at the narrow leg, a resistance factor of
0.70 be applied to the new equation to ensure a reliability index of not less than 3.5 in the LRFD approach of the North American specification for the design of cold-formed steel structures. For single unequal angle braces bolted at the narrow leg, a resistance factor of 0.65 is recommended.

\section{Acknowledgments}

The writers thank John Kralic, Manager, Lysaght Research \& Technology, Bluescope Steel Limited, for supplying the G450 sheet steel materials used in the present work. The specimens were fabricated by Ritchie McLean and tested with the assistance of Jarrod Doyle and Julian Frate, two honors thesis students at the University of Wollongong.

\section{Notation}

The following symbols are used in this paper:

$A_{n}=$ net area of considered section;

$C_{p}=$ correction factor;

$C_{\phi}=$ calibration coefficient;

$c=$ test net section efficiency;

$d=$ bolt diameter;

$F_{m}=$ mean value of fabrication factor;

$F_{u}=$ tensile strength of steel material;

$F_{y}=$ yield stress of steel material;

$k_{t}=$ net section efficiency factor according to AS/NZS 4600:2005;

$L=$ connection length;

$M_{m}=$ mean value of material factor;

$P_{m}=$ mean value of professional factor;

$P_{p}=$ predicted failure load;

$t=$ ominal sheet thickness;

$t_{\text {base }}=$ base metal thickness;

$V_{F}=$ coefficient of variation of fabrication factor;

$V_{M}=$ coefficient of variation of material factor;

$V_{P}=$ coefficient of variation of professional factor;

$V_{Q}=$ coefficient of variation of load effects;

$W_{c}=$ width of connected leg;

$W_{u}=$ width of outstanding leg;

$\bar{x}=$ connection eccentricity;

$\beta_{0}=$ target reliability index;

$\varepsilon_{15}=$ elongation at fracture over a gauge length of $15 \mathrm{~mm}$;

$\varepsilon_{25}=$ elongation at fracture over a gauge length of $25 \mathrm{~mm}$;

$\varepsilon_{50}=$ elongation at fracture over a gauge length of $50 \mathrm{~mm}$;

$\varepsilon_{u o}=$ uniform elongation outside fracture zone; and

$\phi=$ resistance factor (or capacity reduction factor).

\section{References}

AISC. (2010). "Specification for structural steel buildings." ANSI/AISC 360-10, Chicago.

American Iron and Steel Institute (AISI). (2007a). Commentary on North American specification for the design of cold-formed steel structural members, 2007 Ed., American Iron and Steel Institute, Washington, DC.

American Iron and Steel Institute (AISI). (2007b). North American specification for the design of cold-formed steel structural members, 2007 Ed., American Iron and Steel Institute, Washington, DC.

American Iron and Steel Institute (AISI). (2010). Supplement No. 2 to the North American specification for the design of cold-formed steel 
structural members, 2007 Ed., American Iron and Steel Institute, Washington, DC.

Chesson, E. (1959) "Behaviour of large riveted and bolted structural connections," Ph.D. thesis, Univ. of Illinois at Urbana, Urbana, IL.

de Paula, V. F., Bezerra, L. M., and Matias, W. T. (2008). "Efficiency reduction due to shear lag on bolted cold-formed steel angles." J. Construct. Steel Res., 64(5), 571-583.

Hancock, G. J. (2007). Design of cold-formed steel structures, 4th Ed., Australian Steel Institute, Sydney, Australia.

Holcomb, R. D., LaBoube, R. A., and Yu, W. W. (1995). "Tensile and bearing capacities of bolted connections," Second Summary Rep., Civil Engineering Study 95-1, Cold-Formed Steel Series, Dept. of Civil Engineering, Center for Cold-Formed Steel Structures, Univ. of Missouri-Rolla, Rolla, MO.

Kulak, G. L., and Wu, E. Y. (1997). "Shear lag in bolted angle tension members." J. Struct. Eng., 123(9), 1144-1152.

LaBoube, R. A., and Yu, W. W. (1996). "Additional design considerations for bolted connections," Proc., 13th Int. Specialty Conf. Cold-Formed Steel Structures, American Iron and Steel Institute, Washington, DC, 575-593.

Maiola, C. H., Malite, M., Goncalves, R. M., and Neto, J. M. (2002). "Structural behaviour of bolted connections in cold-formed steel members, emphasizing the shear lag effect," Proc., 16th Int. Specialty
Conf. Cold-Formed Steel Structures, American Iron and Steel Institute, Washington, DC, 697-708.

Standards Australia (SA). (1998). "Steel structures." AS 4100-1998, Homebush, Australia.

Standards Australia (SA). (1999). "Steel structures-Commentary." AS 4100-1998, Homebush, Australia.

Standards Australia/Standards New Zealand (SA/SNZ). (2005). "Coldformed steel structures." AS/NZS 4600:2005, Homebush, Australia.

Teh, L. H., and Clements, D. D. A. (2012a). "Block shear capacity of bolted connections in cold-reduced steel sheets." J. Struct. Eng., 138(4), 459-467.

Teh, L. H., and Clements, D. D. A. (2012b). "Tension capacity of staggered bolted connections in cold-reduced steel sheets," J. Struct. Eng., 138(6), 769-776.

Teh, L. H., and Gilbert, B. P. (2012). "Net section tension capacity of bolted connections in cold-reduced steel sheets." J. Struct. Eng., 138(3), 337-344.

Teh, L. H., and Gilbert, B. P. (2013). "Net section tension capacity of cold-reduced sheet steel channel braces bolted at the web," J. Struct. Eng., 10.1061/(ASCE)ST.1943-541X.0000650.

Teh, L. H., and Hancock, G. J. (2005). "Strength of welded connections in G450 sheet steels." J. Struct. Eng., 131(10), 1561-1569. 